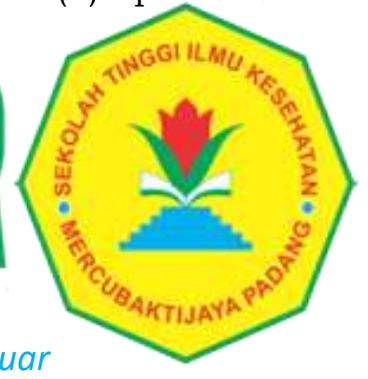

\title{
EFEKTIFITAS ASUHAN KEPERAWATAN KELUARGA TERHADAP PENINGKATAN SELF EFFICACY IBU HAMIL DAN MENYUSUI DALAM PEMBERIAN ASI EKSLUSIF
}

\author{
Maria Ulfah ${ }^{1 *}$ \\ ${ }^{1}$ Program Studi D3 Keperawatan Tegal Poltekkes Kemenkes Semarang \\ Jl. Dewi Sartika No. 1 Debong Kulon Tegal \\ *Email korespondensi: ulfahmaria29@gmail.com
}

\begin{abstract}
ABSTRAK
Family is the main group in maintaining health, and is the main actor in providing care to its members who are giving exclusive breastfeeding. The strategy used is the approach of family and family supporters of ASI. This study aims to provide an overview of the application of ASI-supporting families in increasing self-efficacy. The design of this study was a case study of 10 families with pregnant women and / or nursing mothers taken through purposive sampling technique. The results showed that pregnant and nursing mothers need family support in improving self-efficacy and behavior in breastfeeding.
\end{abstract}

Keywords: Breastfeeding; family; self efficacy

\begin{abstract}
ABSTRAK
Keluarga merupakan kelompok utama dalam mempertahankan kesehatan, serta merupakan pemeran utama dalam memberikan asuhan kepada anggotanya yang sedang memberikan ASI eksklusif. Strategi yang dilakukan adalah dengan pendekatan keluarga dan keluarga pedukung ASI. Penelitian ini bertujuan untuk memberikan gambaran penerapan keluarga pedukung ASI dalam meningkatkan self efficacy. Desain penelitian ini adalah studi kasus pada 10 keluarga dengan ibu hamil dan atau ibu menyusui yang diambil melalui teknik purposive sampling. Hasil penelitian menunjukan bahwa ibu hamil dan ibu menyusui memerlukan dukungan keluarga dalam meningkatkan self efficacy dan perilaku dalam pemberian ASI.
\end{abstract}

Kata kunci: ASI; keluarga; self efficacy

\section{PENDAHULUAN}

Upaya pencapaian prioritas pembangunan kesehatan tahun 2015-2019 dalam program Indonesia sehat dilaksanakan dengan mendayagunakan segenap potensi yang ada, baik dari pemerintah pusat, provinsi, kabupaten/ kota, maupun masyarakat. Pembangunan kesehatan dimulai dari unit terkecil yang ada di masyarakat yaitu keluarga. 
Pembangunan keluarga sebagaimana dimaksud dalam Undang-undang nomor 52 Tahun 2009 tentang perkembangan kependudukan dan pembangunan keluarga serta undang-undang nomor 23 tahun 2014 tentang pemerintah daerah, adalah upaya mewujudkan keluarga berkualitas yang hidup dalam lingkungan sehat Pelaksanaaan Program Indonesia Sehat telah disepakati adanya 12 indikator utama untuk penanda status kesehatan sebuah keluarga. Kedua belas indikator utama tersebut salah satunya adalah bayi mendapat air susu ibu (ASI) eksklusif (Kemenkes, 2016).

Pemberian ASI eksklusif selama 6 bulan bukan hanya tanggung jawab petugas kesehatan, tetapi juga menjadi bagian tanggung jawab keluarga karena pemberian ASI eksklusif berdampak signifikan terhadap kesehatan ibu dan anak. Metode ini juga dianggap metode yang paling ekonomis dan efektif untuk mengurangi morbiditas dan mortalitas anak. Diperkirakan bahwa tindakan yang mempromosikan pemberian ASI dapat mengurangi $13 \%$ jumlah kematian pada anak-anak di bawah usia 5 tahun di seluruh dunia (Gravena et al., 2013).

Dalam pemberian ASI yang perlu diperhatikan bukan hanya bayi yang memperoleh ASI namun kesehatan ibu hamil dan ibu menyusui perlu diperhatikan. Masalah kesehatan ibu hamil dan ibu menyusui dapat memberikan dampak buruk terhadap bayi, individu ibu menyusui, keluarga, komunitas serta negara. Dampak ketidakefektifan pemberian ASI antara lain menurut WHO akan mengakibatkan peningkatan $40 \%$ resiko kematian bayi usia 9-12 bulan jika bayi tersebut tidak diberikan ASI, sedangkan bayi berusia di bawah 2 bulan, angka kematian ini meningkat menjadi $48 \%$. Bayi yang tidak pernah mendapat ASI berisiko meninggal lebih tinggi dibandingkan bayi yang mendapat ASI. Manfaat ASI Eksklusif dapat mengoptimalkan pertumbuhan bayi, membantu perkembangan kecerdasan anak, dan memperpanjang jarak kehamilan ibu. Sedangkan dampak bagi negara yaitu penghematan pada sektor kesehatan, karena jumlah bayi yang sakit hanya sedikit serta memperbaiki kelangsungan hidup anak dengan menurunkan angka kematian (Nurhidayati, 2014).

Perawatan diri keluarga meliputi pengetahuan keluarga, motivasi dan kekuatan atau koordinasi motorik yang diperlukan untuk melakukan tugas perawatan fisik, dan memenuhi kebutuhan dasar anggota keluarga (Friedman et al., 2010). Pengetahuan, keyakinan, dan dukungan adalah faktor yang mempengaruhi niat wanita. Hambatan yang dirasakan, kepercayaan umum, stigma tentang menyusui dan dukungan serta pengaruh dari suami, ibu, anggota keluarga dan kerabat menjadi faktor yang mempengaruhi kelanjutan menyusui pada ibu paska melahirkan (Nuzrina et al., 2016).

Keluarga yang memiliki ibu hamil dan ibu menyusui memiliki peran yang sangat penting dalam perawatan ibu selama hamil dan paska melahirkan atau menyusui. Keluarga berperan dalam memberikan dukungan berupa dukungan sosial. Fungsi utama dukungan sosial adalah meningkatkan kekuatan pribadi yang diberikan dukungan dan mempromosikan pencapaian tujuan hidup. Beberapa sistem dukungan sosial yang berkaitan dengan pemberian ASI adalah natural support system (dukungan keluarga), dukungan 
kelompok sebaya, dan petugas kesehatan. Dukungan dari keluarga (orang tua) seperti memberikan pengalaman menyusui yang telah mereka lakukan kepada ibu menyusui (Mannion et al., 2013). Dukungan dari suami dapat berupa memberikan waktu yang cukup dan suasana yang nyaman selam proses menyusui. Dukungan petugas kesehatan, teman dekat, atau kerabat sangat dibutuhkan oleh ibu, khususnya pada ibu yang baru pertama kali hamil (Masoara, 2013).

Model Family Center Nursing (FCN) menggambarkan keterkaitan dan peran aktif pada keluarga untuk menyelesaikan sebuah masalah yang terjadi didalam sebuah keluarga. Pemberdayaan keluarga dalam hal peningkatan fungsi perawatan dan dapat membantu ibu hamil dan ibu menyusui untuk mampu beradaptasi dengan perubahan yang terjadi, kemampuan berdaptasi membuat ibu hamil dan ibu menyusui mempunyai mampu memberikan ASI yang baik. Model FCN menekankan pada metode asuhan keperawatan yang sistematis, dinamis dan berkelanjutan bertujuan untuk menyelesaikan masalah dengan tahapan pengkajian, diagnosis keperawatan, intervensi dan implementasi, terakhir adalah evaluasi keperawatan (Friedman et al., 2010).

Peningkatan pemberian ASI dengan melibatkan keluarga menggunakan teori FCN merupakan bentuk asuhan keperawatan keluarga yang bersifat promotif dan preventif. Optimalnya peran seorang perawat dalam memberikan asuhan keperawatan keluarga untuk mengoptimalkan pemberian ASI atau mencegah terputusnya pemberian ASI dapat terlihat dari kemandirian keluarga dalam menjalankan fungsi perawatan Kesehatan dalam keluarga.

\section{METODE PENELITIAN}

Metode yang dilakukan adalah studi kasus dengan teknik pengambilan sampel menggunakan purposive sampling artinya sampel yang dipilih sesuai kriteria yang diinginkan peneliti, yaitu dengan cara mengelola 10 kasus keluarga binaan dengan masalah keperawatan ketidakefektifan pemberian ASI eksklusif pada ibu hamil dan ibu menyusui yang diberikan asuhan keperawatan. Studi kasus merupakan metode yang dilakukan peneliti dalam menyelidiki suatu program, aktivitas, proses atau sekelompok individu secara cermat (Creswell, 2016).

Dari 10 keluarga, 6 diantaranya extended family, dan 4 nuclear family namun tinggal bersebelahan dengan orang tua. Keluarga yang diberikan asuhan keperawatan merupakan keluarga pada tahap ibu hamil dengan usia kehamilan trimester 3 (primipara maupun multipara) dan ibu menyusui bayi usia 0-6 bulan, terlebih dahulu dilakukan pengkajian awal yaitu berupa pengetahuan, sikap dan keterampilan keluarga mengenai pemberian ASI eksklusif dan terakhir dilanjutkan dengan melakukan pengkajian self efficacy dengan menggunakan instrumen Breastfeeding Self-efficacy Scale - Short Form (BSES-SF) yang terdiri dari 14 item pertanyaan.

\section{HASIL DAN PEMBAHASAN}

Hasil angket karakteristik pada 10 keluarga binaan yaitu, 7 dari 10 keluarga di bawah UMR Kota Depok, (Rp. 3.046.180,-), 6 orang ibu menyusui dan 4 orang ibu hamil trimester III, dari ke 4 ibu hamil 2 orang adalah ibu primipara dan 2 
orang multipara. dari 6 orang ibu menyusui, 3 orang belum pernah memiliki pengalaman menyusui sebelumnya, dan 3 orang gagal memberikan ASI eksklsuif pada kelahiran anak pertama. Pendidikan rata -rata lulus SMU atau yang sederajat.

Hasil evaluasi didapatan data terjadi perubahan secara signifikan tentang pengetahuan ASI eksklusif, sikap dan keterampilan tentang ASI eksklusif, pada item pengetahuan sebelum intervensi 6 dari 10 keluarga memiliki pengetahuan kurang, setelah intervensi meningkat menjadi 9 dari 10 memiliki pengetahuan baik (IMD, kolostrum, manfaat ASI eksklusif, ASI ibu bekerja, mitos tentang pemberian ASI), sikap meningkat dari 5 keluarga kurang baik menjadi 8 keluarga dengan sikap baik (ASI eksklusif selama 6 bulan, tidak diberikan MP-ASI sebelum 6 bulan, cara yang benar dalam pemberian ASI, teknik perlekatan dan posisi menyusui yang nyaman untuk ibu), sedangkan dari 5 keluarga ketrampilan kurang baik menjadi 8 keluarga dengan ketrampilan baik (menyusui sesuai dengan permintaan bayi, menyusui sampai bayi kenyang, membangunkan bayi jika tidur lebih dari 3 jam pada bayi baru lahir).

Selain peningkatan perilaku tentang ASI eksklusif, terjadi peningkatan self efficacy keluarga dalam pemberian ASI, dari 5 dari 10 keluarga dengan self efficacy rendah meningkat menjadi 8 keluarga dengan self efficacy baik. Sedangkan pada tingkat kemandirian keluarga, digambarkan pada tabel berikut:

\section{Tabel 1. Distribusi Tingkat Kemandirian Keluarga Ibu Hamil dan Ibu Menyusui Sebelum dan Sesudah Dilakukan Intervensi di Kelurahan Curug Tahun 2017 (n = 10)}

\begin{tabular}{|c|c|c|c|}
\hline \multirow[t]{2}{*}{ No } & \multirow[t]{2}{*}{ Keluarga } & \multicolumn{2}{|c|}{ Tingkat Kemandirian Keluarga } \\
\hline & & Sebelum & Sesudah \\
\hline 1 & Keluarga 1 & 1 & III \\
\hline 2 & Keluarga II & 1 & III \\
\hline 3 & Keluarga III & II & III \\
\hline 4 & Keluarga 1V & I & III \\
\hline 5 & Keluarga V & II & IV \\
\hline 6 & Keluarga VI & I & III \\
\hline 7 & Keluarga VII & I & III \\
\hline 8 & Keluarga VIII & I & III \\
\hline 9 & Keluarga 1X & I & III \\
\hline 10 & Keluarga X & I & III \\
\hline
\end{tabular}

Peran keluarga dalam meningkatkan pengetahuan, sikap dan keterampilan ibu hamil dan ibu menyusui dalam meningkatkan pemberian ASI sangat penting (Riasmini et al., 2017). Kemampuan keluarga untuk dapat merawat anggota keluarga dipengaruhi oleh kemampuan keluarga melakukan tugas perawatan kesehatan. Dalam hal ini adalah keluarga mampu mengenal masalah kesehatan, mengambil keputusan yang tepat, merawat anggota keluarga, mampu memodifikasi lingkungan dan mampu memanfaatkan fasilitas Kesehatan (Maglaya, 2010). 
Selanjutnya keluarga juga mempunyai peran yaitu memberi motivasi, kebebasan, perlindungan dan keamanan guna mencapai potensi diri bagi anggota keluarga dengan optimal (Friedman et al., 2010). Dalam hal ini keluarga memberikan motivasi kepada ibu hamil dan ibu menyusui dalam memberikan ASI, perawatan selama kehamilan dan perawatan bayi. Peran yang paling penting adalah keberadaan anggota keluarga bagi ibu hamil dan ibu menyusui.

Peningkatan rerata pengetahuan, sikap dan tindakan pada keluarga diberi asuhan keperawatan menunjukkan peningkatan yang baik. Hasil ini dipengaruhi oleh teknik pemberian implementasi yang dilakukan pada keluarga. Penulis melakukan implementasi keperawatan dengan metoda coaching dan pendidikan kesehatan, demonstrasi serta observasi. Implementasi yang dilakukan pada keluarga merupakan bentuk promosi kesehatan pada bayi, keluarga dan masyarakat untuk mempertahankan kesehatan lebih lama. Kemampuan ibu untuk memberikan perawatan pada bayinya, dipengaruhi oleh faktor internal dan eksternal, kesejahteraan psikologis, dan adanya dukungan social (Salonen et al., 2009).

Pendidikan kesehatan diperlukan pada keluarga yang memiliki bayi (Kaakinen et al., 2018). Pendidikan kesehatan merupakan salah satu intervensi dari tindakan keperawatan yang ditujukan pada klien sebagai individu, keluarga, dan kelompok dalam lingkup promosi kesehatan. Pendidikan kesehatan sebagai intervensi keperawatan, maka perawat harus menerapkan proses pengkajian, diagnosa, perencanaan, implementasi dan evaluasi. Proses keperawatan dilakukan untuk menggali kebutuhan keluarga dan klien untuk menjaga pendidikan kesehatan yang bermutu (Effendi, 2009).

Peningkatan pengetahuan, sikap dan keterampilan ini tidak terjadi pada seluruh keluarga. Masih ada keluarga yang memiliki pengetahuan, sikap dan keterampilan yang kurang, hal ini dapat disebabkan oleh faktor karakteristik keluarga yaitu pendidikan dan ekonomi yang berbeda di setiap keluarga, berdasarkan hasil observasi penulis, keluarga yang memiliki pengetahuan, sikap dan keterampilan kurang terdapat pada keluarga yang memiliki pendapatan dibawah UMR.

Salah satu faktor dominan yang mempengaruhi pola pemberian ASI adalah variabel sosial ekonomi atau pendapatan keluarga. Keluarga dengan sosial ekonomi rendah mempunyai peluang 4,6 kali lebih rendah untuk memberikan ASI dibanding keluarga dengan sosial ekonomi tinggi (Maulida et al., 2016). Pada saat proses pelaksanaan asuhan keperawatan keluarga, keluarga merasa kesulitan dalam melaksanakan anjuran dan intervensi yang diberikan perawat terkait masalah pemberian ASI eksklusif yang dialami anggota keluarga seperti memahami materi yang diberikan perawat dan perlu mengulang kembali materi yang disampaikan di beberapa pertemuan, serta keluarga kesulitan dalam memahami mitos dan fakta tentang pemberian ASI, karena masih percaya dengan nasihat orang tua jaman dulu.

Faktor yang mendukung peningkatan self efficacy antara lain, tingkat pendidikan yang merupakan aspek yang dapat mempengaruhi motivasi ibu menyusui, karena ibu dengan pendidikan tinggi cenderung menyusui lebih lama, memungkinkan untuk menggunakan akses lebih besar terhadap informasi tentang manfaat menyusui. Selain itu, ibu dengan 
kondisi ekonomi lebih baik akan menyusui anak mereka lebih lama dan merasa lebih percaya diri untuk menyusui, karena wanita berpenghasilan rendah biasanya cenderung kurang atau terlambat dalam mengunjungi pelayanan kesehatan (Rodrigues et al., 2013).

Peningkatan self efficacy berhubungan dengan pemberian pendidikan kesehatan kepada keluarga, bahwa keberhasilan ibu merawat bayinya, memberikan ASI dan hubungan positif pada pasangan serta hubungan sosial merupakan bagian kompetensi infant care yang harus dilakukan ibu (Februhartanty et al., 2012). Pendidikan yang diperlukan pada masa childbearing difokuskan pada dukungan untuk peningkatan kemampuan pengambilan keputusan, perilaku dan perawatan untuk menjaga kesehatan bayi. Terdapat evidence based yang menyimpulkan pendidikan kesehatan berhubungan positif terhadap parenting self efficacy, pengetahuan parenting, bonding dan attachment, dan kepuasan ibu pada masa childbearing. Terdapat evidence based yang kuat hubungan antara kepercayaan diri ibu menjalankan perannya dan kemampuan menjalankan kompetensi peran (Jones \& Prinz, 2005).

Faktor lain yang dapat meningkatkan self efficacy yaitu dukungan keluarga, keluarga memiliki kontribusi yang besar dalam keberhasilan keberlangsungan proses menyusui serta sikap positif suami dan keluarga dan partisipasi mereka mengenai ASI yang merupakan salah satu faktor kunci dalam memfasilitasi keberhasilan pemberian ASI, dan jika anggota keluarga memiliki cukup pengetahuan dan keterampilan untuk mendukung pemberian ASI, mereka dapat memberikan dukungan yang lebih efektif dan optimal, hasil penelitian tersebut merekomendasikan bahwa anggota keluarga utama harus dididik dalam memberikan bantuan praktis kepada ibu dalam perawatan bayi dan ibu menyusui serta dukungan ibu yang memadai dalam menyelesaikan masalah menyusui, sehingga mereka dapat membantu ibu dalam pemberian ASI ekslusif (Heidari et al., 2016). Dalam hal ini tampak perlunya dukungan keluarga dalam keberhasilan pemberian ASI eksklusif selama 6 bulan, tidak hanya ibu yang dibekali dengan pengetahuan, sikap serta psikomotor, tetapi keluarga inti atau orang terdekat perlu diberikan pengetahuan, sikap serta psikomotor yang memadai.

Ibu yang mendapat dukungan dari anggota keluarga, terutama suami atau pasangan dan kakek nenek, memiliki pengaruh positif terhadap self-efficacy of breastfeeding (Gursoy et al., 2009). Agar dukungan ini terwujud, anggota keluarga harus dilibatkan dalam mempromosikan ASI eksklusif baik yang masih hamil atau yang sudah melahirkan, sehingga bisa mendukung ibu dan membantu ibu merasa mampu menyusui.

Intervensi ini berdampak pada tingkat kemandirian keluarga. Kemandirian keluarga yang dinilai berdasarkan kelima tugas kesehatan keluarga (Kemenkes, 2016). Pendidikan kesehatan yang dilakukan di keluarga sebagain besar diikuti oleh ibu hamil/ menyusui dan hanya dua keluarga yang diikuti kepala keluarga karena rata-rata kepala keluarga bekerja. Intervensi keperawatan yang diberikan keluarga untuk meningkatkan kesehatan keluarga harus secara menyeluruh beserta anggota keluarga lainnya (Friedman et al., 2010).

Hasil tingkat kemandirian keluarga dari 10 keluarga hanya 9 keluarga berada pada tingkat kemandirian III hal ini disebabkan karena keluarga belum mampu melakukan tindakan promotif secara aktif di lingkungan 
masyarakat terkait dengan pemberian ASI eksklusif, hanya 1 keluarga yang mampu mencapai tingkat kemandirian IV karena keluarga tersebut sudah mampu melakukan tindakan promotif dilingkungan rumah secara aktif dengan cara mengajak tetangga disekitar rumahnya untuk datang ke posyandu/ posbindu dan sering mengingatkan tetangganya untuk tetap memberikan ASI minimal selama 6 bulan.

Peningkatan kemandirian keluarga adalah bentuk keberhasilan asuhan keperawatan keluarga (Putri \& Riasmini, 2013), dalam hal ini terjadi peningkatan kemandirian kemampuan keluarga dalam melaksanakan tugas perawatan keluarga dengan optimal salah satunya adalah dalam upaya meningkatnya pemberian ASI pada bayi.

Keluarga dalam memberikan intervensi harus melalui pemberdayaan sumber-sumber dan potensi yang ada termasuk sumber perawatan diri, sistem dukungan dalam keluarga, sumber bantuan fisik serta sumbersumber yang ada di komunitas (Friedman et al., 2010). Keluarga sebagai sistem pendukung perawatan ibu hamil dan ibu menyusui diharapkan mampu memberikan dukungan dan memiliki jaringan sosial dalam komunitas untuk menjalankan fungsi keluarga yang efektif (Nurhidayati, 2014).

Hambatan yang dijumpai saat melakukan asuhan keperawatan adalah permasalahan kemauan klien dan keluarga dalam mempersiapkan diri sejak dini untuk dalam memberiakan ASI eksklusif dengan aktif mengikuti kegiatan di masyarakat atau aktif bertanya dan konsultasi pada saat pemeriksaan kandungan di puskesmas atau pelayanan kesehatan lainnya minimal pada saat trimester III kehamilan.

\section{SIMPULAN}

Berdasarkan hasil penelitian terdapat pengaruh antara dukungan keluarga dengan peningkatan self efficacy pemberian ASI pada ibu hamil dan ibu menyusui.

Penelitian ini dapat dijadikan bahan pertimbangan dalam pemberian asuhan keperawatan keluarga pada pada keluarga dengan ibu hamil dan ibu menyusui bahwa keberhasilan pemberian ASI eksklusif bukan hanya melibatkan ibu hamil/ ibu menyusui saja tetapi juga dipengaruhi kontribusi dan peran serta keluarga dalam memberikan informasi, motivasi, kenyamanan, sarana dan prasarana yang menunjang serta dukungan emosional yang dapat menurunkan tingkat kecemasan dan stress dalam pemberian ASI sehingga ibu menyusui dapat memberikan ASI eksklusif secara optimal.

\section{UCAPAN TERIMAKASIH}

Ucapan terima kasih kami ucapkan pada semua pihak yang telah mendukung untuk proses pelaksanaan studi kasus ini terkhususnya kami ucapkan pada Puskesmas Cimanggis Depok, Ketua RW 06 Kelurahan Curug dan Poltekkes Kemenkes Semarang.

\section{DAFTAR PUSTAKA}

Creswell, J. W. (2016). Research Design: Pendekatan Metode Kualitatif, Kuantitatif, Dan Campuran. Yogyakarta: Pustaka Pelajar.

Effendi, F. M. (2009). Keperawatan Kesehatan Komunitas: Teori dan Praktek Dalam Keperawatan. Jakarta : Salemba Medika.

Februhartanty, J., Wibowo, Y., Fahmida, U., \& Roshita, A. (2012). Profiles of eight working mothers who practiced exclusive breastfeeding in Depok, Indonesia. Breastfeeding Medicine, 


\section{7(1), 54-59.}

Friedman, M. M., Bowden, V. R., \& Jones, E. G. (2010). Textbook of Family Nursing Research, Theory and Practice. Interpreting, Achir Yani S. Hamid, et al; Editor of the Indonesian edition, Estu Tiar. Jakarta: EGC.

Gravena, A. A. F., Paula, M. G. de, Marcon, S. S., Carvalho, M. D. B. de, \& Pelloso, S. M. (2013). Maternal age and factors associated with perinatal outcomes. ACTA Paulista de Enfermagem, 26(2), 130-135.

Gürsoy, A. A., Yiğitbaş, C., Yilmaz, F., Erdöl, H., Bulut, H. K., Mumcu, H. K., Calik, K. Y., Kahriman, I., Hintistan, S., \& Nural, N. (2009). The effects of peer education on university students' knowledge of breast self-examination and health beliefs. Journal of Cancer Education: The Official Journal of the American Association for Cancer Education, 24(4), 331-333. https://doi.org/10.1080/0885819090299 7449

Heidari, Z., Keshvari, M., \& Kohan, S. (2016). Breastfeeding promotion, challenges and barriers: a qualitative research. International Journal of Pediatrics, 4(5), 1687-1695.

Jones, T. L., \& Prinz, R. J. (2005). Potential roles of parental self-efficacy in parent and child adjustment: A review. Clinical Psychology Review, 25(3), 341-363.

Kaakinen, J. R., Coehlo, D. P., Steele, R., \& Robinson, M. (2018). Family health care nursing: Theory, practice, and research. FA Davis.

Kemenkes, R. I. (2016). Pedoman Umum Program Indonesia Sehat Dengan Pendekatan Keluarga. Jakarta: Kemenkes RI.

Maglaya, A. (2010). Nursing practice in the community (5th ed.). Argonauto Corporation.
Mannion, C. A., Hobbs, A. J., McDonald, S. W., \& Tough, S. C. (2013). Maternal perceptions of partner support during breastfeeding.

International Breastfeeding Journal, 8(1), 4.

Masoara, S. (2013). Manfaat ASI Untuk Bayi, Ibu Dan Keluarga. Jakarta: Perkumpulan Perinatologi Indonesia.

Maulida, H., Afifah, E., \& Pitta Sari, D. (2016). Tingkat Ekonomi dan Motivasi Ibu dalam Pemberian ASI Eksklusif pada Bayi Usia 0-6 Bulan di Bidan Praktek Swasta (BPS) Ummi Latifah Argomulyo, Sedayu Yogyakarta. Jurnal Ners Dan Kebidanan Indonesia, $3(2)$, 116. https://doi.org/10.21927/jnki.2015.3(2). 116-122

Nurhidayati, I. (2014). Pengaruh Kelompok Swabantu ASIEKs DALAM Meningkatkan Perilaku Pemberian ASI Ekslusif Pada Agregat Ibu Hamil Dan Menyusui Di Wilayah Kelurahan Curug Cimanggis Kota Depok. Karya Ilmiah Akhir Spesialis: Depok Fakultas Ilmu Keperawatan Universitas Indonesia [Tidak Diterbitkan].

Nuzrina, R., Roshita, A., \& Basuki, D. N. (2016). Factors affecting breastfeeding intention and its continuation among urban mothers in West Jakarta: A follow-up qualitative study using critical point contact for breastfeeding. Asia Pacific Journal of Clinical Nutrition, 25(9), S43-S51. https://doi.org/10.6133/apjen.122016.s1 0

Putri, Y. S. E., \& Riasmini, N. M. (2013). The Predictors of Caregiver's Burden and Depression Level in Caring Elderly People with Dementia at Community. Jurnal Ners, 8(1), 88-97.

Riasmini, N. M., Permatasari, H., Chairani, R., Astuti, N. P., Ria, R., \& Handayani, T. W. (2017). Panduan Asuhan Keperawatan Individu, Keluarga, 
Kelompok, Dan Komunitas Dengan

Modifikasi NANDA, ICNP, NOC Dan

NIC Di Puskesmas Dan Masyarakat.

Jakarta: UI-Press.

Rodrigues, A. P., de Mello Padoin, S. M., de

Paula, C. C., \& de Azevedo Guido, L.

(2013). Factors those influence in self-

efficacy of breastfeeding: an integrative

review. Journal of Nursing UFPE on

Line, 7(5), 1522-1530.

Salonen, A. H., Kaunonen, M., Åstedt- Kurki, P., Järvenpää, A., Isoaho, H., \& Tarkka, M. (2009).

Parenting self- efficacy after childbirth. Journal of Advanced Nursing, 65(11), 2324-2336. 